\section{Is COVID-19 Created or Designed?}

\author{
S. Joshua Swamidass (D) \\ https://doi.org/10.54739/irmq
}

OVID-19 is growing. I was stuck at home in quarantine, which was thankfully lifted. A Veritas Forum in which I was supposed to speak next week was cancelled. Universities across the country are cancelling classes. Professors are scrambling to put the courses online.

I am lost in greater questions. Where do viruses come from? Did God create viruses? Or did God design them? Is there a difference between creating and designing them?

I am a scientist, but these questions bring me to theology. Luckily, I am in a book study with The Creation Project of Trinity Evangelical Divinity School. We are reading and discussing a book on the theology of divine action: The Providence of God: A Polyphonic Approach. I am reading closely in preparation for a presentation March 27-28 about how I brought the scientific method into dialogue with the de novo creation of Adam and Eve in The Genealogical Adam and Eve. So, I am a scientist wondering about theology.

In a world turned upside down by a new virus, I am wondering. Is there a difference between "designed" and "created"? Is it possible God created the SARS-CoV-2 virus that causes COVID-19, but at the same time did not design the virus?

\section{Created or Designed?}

I believe that God created all things, and in this sense I believe that God designed all things. That being said, I prefer the theological term "create" to the word "design." I think this makes a difference. We cannot treat these terms as stand ins for one another.

"Design" is defined to be the "action of a mind." In his presentation, Behe went so far as to say that the purposeful arrangement of parts is the only way we recognize a mind. I'm not at all sure the validity of that total claim, but it makes clear that he links design to the action of a mind. "Design," also, is deeply aligned with intention and purpose. Perhaps most importantly to discussion of God's action, "design" is not the term used in the doctrine of creation.

"Create," in contrast, is the term used in the doctrine of creation. Historically, there has been much contemplation about how to hold together the fact that (1) God created all things but (2) many things in creation are not the direct result of his purpose or intention. For example, natural disasters might be understood as arising out of the natural processes of the world.

Theologically, we seem to affirm some distance between God's direct intention and action in the world, on the one hand, and natural disasters that take place in the created world, on the other hand. Certainly God governs all things, and He created all things, but $\mathrm{He}$ is

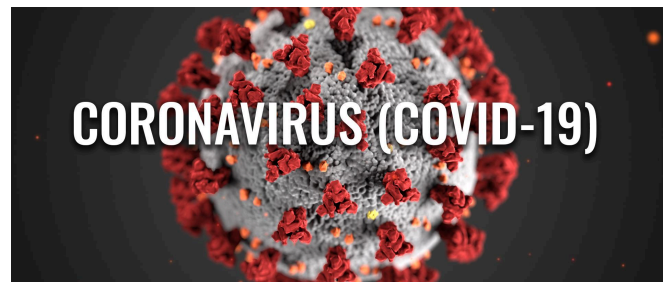

not directly intending all things, is He? Most of us, it seems, would affirm that God created Hurricane Katrina and that He providentially governs the weather. Still, most of us would stop short of saying $\mathrm{He}$ designed this disaster.

\section{Behe Theologizes COVID-19}

A couple weeks ago, I presented my understanding of evolution alongside Michael Behe, a leading ID proponent. We agree on quite a bit. For example, we both agree that there is strong evidence that humans share common ancestors with the great apes: chimpanzees, bonobos, gorillas, and orangutans. We also agree that God created all things.

Still, I disagree with Dr. Behe about his arguments for design. As I've explained in the past, his arguments for design look like $1+1=3$ to me. Rather than litigate this disagreement, however, I hoped to understand him better.

I learned something new. One of the most striking parts of Mike's presentation was a beautiful animation of a virus injecting DNA into a cell. He presented this as an example of design, appealing to the audience's intuition. After all, it really did appear designed.

I asked him a question, “do you really think God designed viruses?”

Mike answered, explaining that God did design the viruses, but cautioning that biology and God's action was non-intuitive. I think Mike is right on this, even though it runs against our intuitions. Theology and science are both non-intuitive this way.

I was pleased to see him write an article expanding his theology of viruses. Considering COVID-19, he concludes,

In the same way, most viruses do not affect humans and may well have a positive, necessary role to play in nature of which we are currently unaware. (I would bet on it.) From time to time a storm arises in the virosphere and affects humans. But that's no reason to think either that viruses weren't designed or that the designer of viruses isn't good.

So, to restate his point: viruses are designed, but when a virus, like the one causing COVID-19, evolves, we should understand it much like a storm. The point here, it seems, is that the changes required for the COVID-19 virus to infect and injure humans arise from the natural operation of the world, not God's intended purpose or design. To make this move, Behe is acknowledging some relative autonomy to creation, that it operates under God's governance but also somehow "on its own." 
So the virus is designed, but its evolution into a disease causing pathogen is not designed.

This seems about right to me. Moreover, it seems that this is a good way to understand cancer too. It seems similar moves are made by Young Earth Creationists too. Certainly, these distinctions are difficult for atheist observers, but that is partly because the discussion in ID is disconnected from the history of theological discourse here. It was still helpful to see Behe's theology come through.

\section{A Theological "Control" for Design}

I am not an ID proponent, but I wonder if theology is the missing piece in the Intelligent Design Movement.

If we see evidence that evolution can do something surprising, we can just assert that this was due to God's design. To study what biological systems can do on their own, we need to study biological systems operating on their own, without God's design. If we mean God's "design" to be intention and purposeful involvement towards a specific end, what are the biological changes He did not design?

\section{References}

https://peacefulscience.org/books/providence-god/

https://www.covenantseminary.edu/events/henry-center-theologyconference-divine-action-and-scientific-integrity

https://peacefulscience.org/books/genealogical-adam-eve/

https://youtu.be/6Pi5UoZkn4g

https://peacefulscience.org/articles/agree-behe/

https://peacefulscience.org/articles/evidence-and-evolution/
It seems that this question is critical to answer, and it can only be answered by theology. Perhaps the evolution of viruses is one example of creation without design, and perhaps the evolution of cancer is another. Could these be "theological controls," where biology can be studied without appealing to "design," even if we believe God "created" all things? What other controls could we find?

I am not sure though how to settle these questions from science alone. It seems we need to engage deeply with theology.

In the end, if God created all things, then in this sense He designed us all. Considering the theology of viruses, we should still be clear; creation is not design and design is not creation.

Edited March 12, 2020 to clarify the distinction between the virus SARS-CoV-2 and the disease COVID-19 that it causes. Thanks to Zachary Ardern for catching this mistake.

https://peacefulscience.org/articles/garden-path/

https://evolutionnews.org/2020/03/evolution-design-and-covid-19

https://peacefulscience.org/articles/cancer-evolution/

https://creation.com/did-god-make-pathogenic-viruses

https://sensuouscurmudgeon.wordpress.com/2020/03/11/beheexplains-the-coronavirus 